\title{
MAP Kinase-Activated Protein Kinase 2
}

National Cancer Institute

\section{Source}

National Cancer Institute. MAP Kinase-Activated Protein Kinase 2. NCI Thesaurus. Code C114359.

MAP kinase-activated protein kinase 2 (400 aa, $\sim 46 \mathrm{kDa}$ ) is encoded by the human MAPKAPK2 gene. This protein is involved in stress responsive signaling. 